\title{
Genetics and Anthocyanin Analysis of Flower Color in Mexican Petunia
}

\author{
Rosanna Freyre ${ }^{1,5}$ \\ University of Florida, Institute of Food and Agricultural Sciences, Environmental Horticulture \\ Department, P.O. Box 110670, Gainesville, FL 32611
}

Chad Uzdevenes ${ }^{2}$ and Liwei $\mathbf{G u}^{3}$

University of Florida, Institute of Food and Agricultural Sciences, Food Science and Human Nutrition

Department, P.O. Box 110370, Gainesville, FL 32611

\author{
Kenneth H. Quesenberry ${ }^{4}$ \\ University of Florida, Institute of Food and Agricultural Sciences, Agronomy Department, P.O. Box \\ 110500, Gainesville, FL 32611
}

\begin{abstract}
AdDitional INDEx words. Acanthaceae, flavonoid pathway, high-performance liquid chromatography, mass spectrometry, Ruellia simplex

Abstract. The genetics and anthocyanins responsible for flower color were studied in Ruellia simplex Wright (mexican petunia). An $\mathrm{F}_{2}$ population with 153 individuals segregating for four flower colors was developed from a cross between a maternal individual with white corolla with purple throat (WP) and a paternal individual with pink corolla (PK). All the $F_{1}$ generation had fully purple flowers $(P)$. The $F_{2}$ generation segregated 94 P:30 PK:24 WP:5 WPK (WPK is a new color combination of white corolla limb and pink throat). These data were separated into groups for corolla limb color and for throat color. The ratio for corolla limb color segregated 94 P:30 PK:29 W, which fits a 9:3:4 recessive epistasis interaction $(P=0.22)$. The data for corolla throat segregated 118 $P: 35 P K$, which fits a 3:1 ratio $(P=0.54)$. High-performance liquid chromatography mass spectrometry analyses were performed to elucidate the anthocyanins responsible for the four obtained flower colors. We found that delphinidin derivatives conferred purple corolla color, whereas pelargonidin derivatives were responsible for the pink corolla color. Purple corolla throat color was the result of delphinidin derivatives, whereas the pink color was the result of peonidin derivatives.
\end{abstract}

There are $\approx 350$ species of Ruellia L. (Acanthaceae) that are perennial herbs, subshrubs, or shrubs with mostly tropical and subtropical distributions (Tripp and McDade, 2014). A chromosome number of $2 n=2 \mathrm{X}=34$ appears to be widespread in this large genus (Daniel et al., 1984, 1990; Daniel and Chuang, 1993). The most commonly found Ruellia species in southeastern U.S. gardens is Ruellia simplex (britton's petunia, mexican petunia, or mexican bluebell). Scientific names for this plant that have been used throughout the botanical and horticultural literature include $R$. brittoniana Leonard, $R$. coerulea Morong, $R$. malacosperma Greenm., and $R$. tweediana Griseb. These names have been reduced to synonyms of the oldest name and thus that with priority, R. simplex (Ezcurra and Daniel, 2007). The wild form of this species is found in sunny areas on periodically inundated soils in Mexico, the Antilles, and central western South America (Ezcurra and Daniel, 2007). It was introduced to Florida sometime before 1940 (Hupp et al., 2009) and is now a very popular landscape plant as a result of its low maintenance requirements and copious flowering (Gilman, 1999).

Received for publication 10 Sept. 2014. Accepted for publication 12 Nov. 2014. This work was supported by the USDA/Tropical and Subtropical Agriculture Research (TSTAR) program grant No. 0093296 and the University of Florida/Institute of Food and Agricultural Sciences.

We thank Madeline Bottenhorn, Zachary Bell, Brian Owens, and Mark Kahn for their technical assistance with greenhouse and field plants.

${ }^{1}$ Research Scientist.

${ }^{2} \mathrm{MS}$ Student.

${ }^{3}$ Associate Professor.

${ }^{4}$ Professor Emeritus.

${ }^{5}$ Corresponding author. E-mail: rfreyre@ufl.edu.
Flower colors are attributable primarily to flavonoid and carotenoid pigments and are inferred to serve to attract pollinators (Davies, 2004). Flavonoids are the most common flower color pigment, and the predominant flavonoid pigments are the anthocyanins. Anthocyanins are composed of an anthocyanidin and sugar moieties. They are the basis for most orange, pink, red, magenta, purple, blue, and blue-black floral colors. The common anthocyanidins are pelargonidin, cyanidin, peonidin, delphinidin, petunidin, and malvinidin, named for the genera from which they were first isolated. Most anthocyanins are derived from just the following three basic anthocyanidin types: pelargonidin, cyanidin, and delphinidin (Schwinn and Davies, 2004). Cyanidin and delphinidin can be further modified by glycosylation, methylation, and acylation to form peonidin and malvidin, respectively (Holton and Cornish, 1995). Orange and pink colors tend to be based on pelargonidin derivatives, magenta colors on cyanidin derivatives, and purple and blue colors on delphinidin derivatives (Harborne, 1976). Flowers can accumulate mixtures of anthocyanin types, providing further variation in color. Other factors such as vacuolar $\mathrm{pH}$ and petal cell shape can also affect the flower color (Mol et al., 1998). The genetics of flower color are best known in Petunia $\times$ hybrida Vilm, where nine major genes involved in the inheritance of flower color were initially identified (Paris and Haney, 1958). Based on biochemical data, these genes were assigned specific functions in the biosynthetic pathway (Forkmann, 1991; Holton and Cornish, 1995; Mol et al., 1998; Wiering and deVlaming, 1984). Additionally, genetic differences in flower color resulting from modifications 
in the $\mathrm{pH}$ were explained by genes $P h 1, P h 2$, and Ph6 (Griesbach, 1996, 1998).

Flower morphology, flower size, and flower color in Ruellia are varied. Flower color ranges from white, cream, yellow, lavender, purple, pink, magenta, and red (Tripp, 2014). However, the range of flower colors in $R$. simplex is more limited. The wild-type and cultivars Purple Showers and the dwarf Purple Katie have purple flowers [Royal Horticultural Society (RHS) 87A (Royal Horticultural Society, 1995)]. Over the years, cultivars with the following other colors have become available: pink-flowered Chi Chi and Pink Katie (RHS 66D) and white-flowered Snow White and White Katie (RHS 155D). All purple and pink-flowered forms have a darker throat (either dark purple RHS 86B or dark pink RHS 74A, respectively). Additionally, in 2010, a mutant with white corolla and purple throat was found in cultivation in Vero Beach, FL (S.B. Wilson, personal communication), although not commercially available. Breeding efforts at the University of Florida have resulted in the recent release of non-invasive, sterile cultivars Mayan Purple, Mayan White (Freyre et al., 2012), and Mayan Pink (Freyre and Wilson, 2014).

In this study, we developed an $\mathrm{F}_{2}$ population segregating for flower color in $R$. simplex from a cross of an individual with white corollas with purple throat and an individual with pink corollas. We were then able to elucidate the genetic control for flower color in this species. We also performed highperformance liquid chromatography mass spectrometry analyses to determine the anthocyanins responsible for four flower colors in $R$. simplex.

\section{Materials and Methods}

\section{Parental plant material}

The maternal parent was a true-breeding $R$. simplex mutant with white corollas and purple throat [WP (found in Vero Beach, FL)], whereas the paternal parent was true-breeding pink-flowered $R$. simplex 'Chi Chi' [PK (cultivar from Boynton Botanicals, Palm Beach, FL)]. Plants were maintained in greenhouses at the University of Florida, Gainesville. Plants were grown in 1-L pots with soilless mix $(60 \%$ Canadian peatmoss, 40\% perlite; Fafard 2P; Concord Fafard, Agawam, MA) and placed on benches in an insect-proof greenhouse. Plants were watered as needed with $0.15 \mathrm{~g} \cdot \mathrm{L}^{-1}$ nitrogen using $20 \mathrm{~N}-4.4 \mathrm{P}-16 \mathrm{~K}$ water-soluble fertilizer (Everris Americas, Dublin, $\mathrm{OH})$.

\section{Hybridizations}

Hybridizations were conducted in July 2011. Fully expanded flower buds (within which the anthers had not dehisced pollen) on the maternal plant WP were emasculated by removing the corollas and attached anthers. Immediately afterward, the stigmas were hand-pollinated using pollen from anthers freshly collected from the paternal plant PK. The pollinated gynoecia were then tagged with a colored plastic string. A total of seven flowers was pollinated. When the fruit developed, they were enclosed with an empty tea bag secured with a paper clip to prevent loss of seeds during fruit dehiscence (fruit of Acanthaceae have explosive dehiscence). When fruit dehisced naturally, seeds were collected in a coin envelope. Seeds were counted and immature or damaged seeds were discarded. Seeds were maintained in a glass desiccator under room temperature until sowing.
$\mathbf{F}_{1}$. In Jan. 2012, $\mathrm{F}_{1}$ seeds were sown $\approx 1 \mathrm{~cm}$ deep in a 20 -row seeder tray (Landmark Plastics, Akron, OH) using pre-wetted soilless mix. The seed tray was placed in a polycarbonate mist house (with 30\% light irradiance) for $15 \mathrm{~d}$ and received misting from 0800 to $1800 \mathrm{HR}$ (5 s every $30 \mathrm{~min})$. Temperature was maintained between 18 to $24{ }^{\circ} \mathrm{C}$. The tray was then taken to the greenhouse and $15 \mathrm{~d}$ later seedlings were initially transplanted into six-packs and later into $10-\mathrm{cm}$ substrate paper pots (Blackmore Co., Belleville, MI). When $\mathrm{F}_{1}$ plants had more than two branches, two cuttings were pinched from each plant, stuck in 128-cell cutting trays with soilless mix, placed under mist in a research greenhouse for $15 \mathrm{~d}$, and then into $10-\mathrm{cm}$ substrate paper pots.

On 15 May 2012 all substrate paper pots of the original $F_{1}$ plants were transplanted to a field at the Plant Sciences Research and Education Unit (PSREU) at Citra, FL. The field was fumigated for nematodes and weeds 3 weeks before planting and rototilled. Rows were formed by raising $10 \mathrm{~cm}$ off the ground and covered with silver plastic. Plants were transplanted on holes punched on center on the rows and spaced $50 \mathrm{~cm}$ apart. Each plant was top-dressed with $\approx 9 \mathrm{~g}$ of $15 \mathrm{~N}-4 \mathrm{P}-$ $10 \mathrm{~K}$ controlled-release granular fertilizer (Scotts, Marysville, $\mathrm{OH})$. Irrigation was through drip tapes under the rows and supplied as needed.

$\mathbf{F}_{2}$. Nine $F_{1}$ plants that had been kept in the greenhouse were potted up into $15-\mathrm{cm}$ traditional standard plastic pots (Kord, Reidsville, NC), whereas the rest were discarded. The $\mathrm{F}_{1}$ plants were grown to maturity in the greenhouse, and two to three fruit from self-pollination were harvested from each plant. Twenty seeds from each $\mathrm{F}_{1}$ plant were sown as described previously on 14 Nov. 2012 to produce the $F_{2}$ generation. $F_{2}$ plants were maintained in the greenhouse in substrate paper pots until field transplant at the PSREU in Citra on 25 Apr. 2013 following the procedures described previously. Flower color was noted as each plant flowered.

\section{Sample extraction for anthocyanin analysis}

Flowers for each of the four colors were collected from several $\mathrm{F}_{2}$ plants. For each color, the corollas were separated from the rest of the flower and cut into small pieces using scissors. One gram of corolla tissue for each color was soaked in $10 \mathrm{~mL}$ of methanol (containing $3 \%$ acetic acid $\mathrm{v} / \mathrm{v}$ ) in a $30-\mathrm{mL}$ glass test tube for $20 \mathrm{~min}$. The test tubes were sonicated for an additional $10 \mathrm{~min}$. The samples were transferred to $15-\mathrm{mL}$ plastic tubes and centrifuged at $1107 g_{\mathrm{n}}$ for $10 \mathrm{~min}$. The supernatant was transferred back to $30-\mathrm{mL}$ glass tubes, capped, and placed in a freezer in the dark until further analysis.

\section{Total anthocyanins analysis}

The extracts were diluted to appropriate concentration for analysis. The total anthocyanin content was measured using the $\mathrm{pH}$ differential spectrophotometric method described by Giusti and Wrolstad (2001). The extracts were diluted with 0.025 $\mathrm{mol} \cdot \mathrm{L}^{-1}$ potassium chloride buffer, $\mathrm{pH} 1.0$, and $0.4 \mathrm{~mol} \cdot \mathrm{L}^{-1}$ sodium acetate buffer, $\mathrm{pH} 4.5$, to the predetermined dilution factor. The samples were incubated at room temperature in darkness for $15 \mathrm{~min}$ and then the absorbance at 520 and $700 \mathrm{~nm}$ was measured using a spectrophotometer (DU 730 Life Science; Beckman Coulter, Fullerton, CA). The results were reported as milligrams of cyanidin 3,5-diglucoside equivalents per gram of fresh flowers. This was calculated using the formula: $(\mathrm{A} \times \mathrm{MW}) /(\varepsilon)$, where the absorbance $(\mathrm{A})$ was 
calculated as $\left(\mathrm{A}_{520}-\mathrm{A}_{700}\right)_{\mathrm{pH} 1.0}-\left(\mathrm{A}_{520}-\mathrm{A}_{700}\right)_{\mathrm{pH} 4.5}$, the molecular weight [MW (611)] was of cyanidin 3,5-diglucoside, and the molar absorptivity $(\varepsilon)$ was of cyanidin 3,5-diglucoside (30175). Total anthocyanin means for each flower color were statistically compared using Tukey-Kramer honestly significant difference.

\section{High-performance liquid chromatography-diode array detector-mass spectrometry analysis}

A high-performance liquid chromatography system (1200; Agilent Technologies, Palo Alto, CA) containing an autosampler, a binary pump, a column compartment, a diode array detector, a fluorescent detector, and a refractive index detector

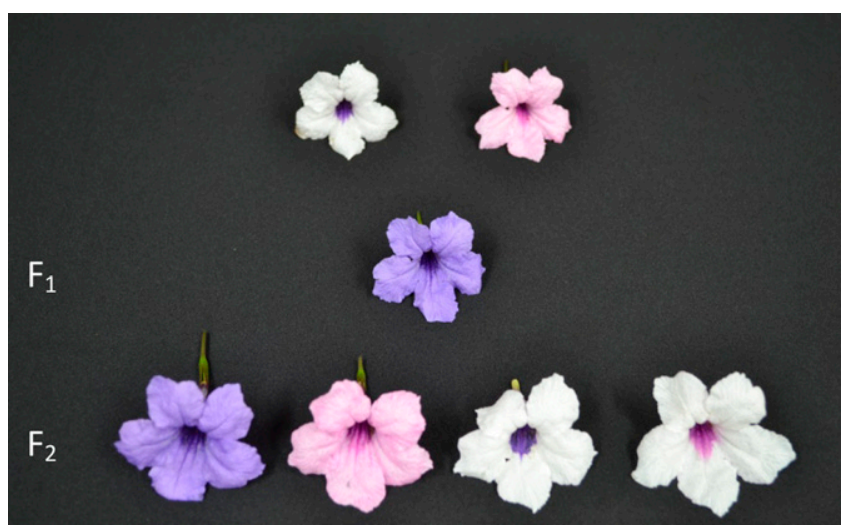

Fig. 1. Flowers of the maternal Ruellia simplex individual with white corolla with purple throat, the paternal individual with pink corolla, one individual representing the $F_{1}$ population with purple corollas, and the $F_{2}$ population segregating for corolla color.

Table 1. Total anthocyanin content of Ruellia simplex with pink, purple, white with purple throat, or white with pink throat corolla color.

\begin{tabular}{lc}
\hline Corolla color & $\begin{array}{c}\text { Total anthocyanins } \\
{\left[\text { mean } \pm \text { SD }\left(\mathrm{mg} \cdot \mathrm{g}^{-1} \mathrm{dry} w \mathrm{wt}\right)\right]^{\mathrm{z}}}\end{array}$ \\
\hline Purple & $86.3 \pm 3.4 \mathrm{a}^{\mathrm{y}}$ \\
Pink & $26.1 \pm 6.6 \mathrm{~b}$ \\
White with purple throat & $11.5 \pm 0.1 \mathrm{~b}$ \\
White with pink throat & $10.8 \pm 1.1 \mathrm{~b}$
\end{tabular}

${ }^{\mathrm{z}}$ Mean of duplicate samples.

y Values with the same letter are not significantly different using Tukey-Kramer honestly significant difference $(P<0.005)$. was used for anthocyanin analysis. Separation of the anthocyanins was achieved using a $250 \times 4.6-\mathrm{mm}, 5-\mu \mathrm{m}$ column (Agilent Technologies). Elution was performed using mobile phase A (5\% acetic acid aqueous solution) and mobile phase B (methanol). Ultraviolet-vis spectra were scanned from 180 to $600 \mathrm{~nm}$ on a diode array detector with a detection wavelength of $520 \mathrm{~nm}$. A flow rate of $1 \mathrm{~mL} \cdot \mathrm{min}^{-1}$ with a $50-$ min gradient was used as follows: 0 to $2 \mathrm{~min}, 5 \% \mathrm{~B} ; 2$ to $10 \mathrm{~min}, 5 \%$ to $15 \% \mathrm{~B} ; 10$ to $25 \mathrm{~min}, 15 \%$ to $25 \% \mathrm{~B} ; 25$ to $30 \mathrm{~min}, 25 \%$ to $30 \% \mathrm{~B} ; 30$ to $45 \mathrm{~min}, 30 \% \mathrm{~B} ; 45$ to $47 \mathrm{~min}, 30 \%$ to $70 \% \mathrm{~B}$; and 47 to $50 \mathrm{~min}$, $70 \%$ to $5 \% \mathrm{~B}$ followed by $5 \mathrm{~min}$ of re-equilibration of the column between samples. Electrospray mass spectrometry was performed with a high-capacity ion trap mass spectrometer (Bruker Daltonics, Billerica, MA). Column effluent was monitored in the positive ion mode. The following conditions for the mass spectrometer were used: nebulizer $(310.3 \mathrm{kPa})$, dry gas $\left(11.0 \mathrm{~L} \cdot \mathrm{min}^{-1}\right)$, dry temperature $\left(350^{\circ} \mathrm{C}\right)$, ion trap (scan from $\mathrm{m} /$ z 150 to 1500 ), smart parameter setting compound stability $(50 \%)$, and trap drive level $(60 \%)$. The mass spectrometer was operated in Auto $\mathrm{MS}^{2}$ mode to capture and fragment the most abundant ion in full scan mass spectra.

\section{Results and Discussion}

Four fruit were harvested from the seven crosses performed between $\mathrm{WP} \times \mathrm{PK}$. Seeds were sown and $66 \mathrm{~F}_{1}$ seedlings were obtained. A total of 55 plants flowered in the field in 2012, and all were found to have purple flowers. $F_{2}$ seeds were sown and a total of 155 seedlings germinated and were transplanted to the field in 2013. A total of 153 plants flowered and their flower color was noted. Segregation of flower color was observed in the $\mathrm{F}_{2}$ generation. In addition to the purple, pink, and white with purple throat colors, a new combination of white with pink throat was recovered (Fig. 1). The segregation observed was 94 P:30 PK:24 WP:5 WPK.

Samples of each of the four distinct color patterns were used to determine the anthocyanin concentrations for each flower color. The tentative identification indicated that all the anthocyanins detected were diglucosides. Interestingly, it was found that the purple color had more than three times the amount of anthocyanin compared with the pink color (Table 1).

With the high-performance liquid chromatography-diode array detector-mass spectrometry analysis, the anthocyanin responsible for the purple color was tentatively identified as malvidin as a result of a combination of malvidin 3,5-diglucoside

Table 2. Retention times and mass spectrometric (MS) data of anthocyanins in Ruellia simplex determined by high-performance liquid chromatography-diodide array detector-mass spectrometry.

\begin{tabular}{|c|c|c|c|c|c|c|}
\hline Flower color & Compound & $\begin{array}{l}\text { Retention } \\
\text { time (min) }\end{array}$ & $\begin{array}{c}\text { Molecular } \\
\text { wt }\end{array}$ & $\mathrm{MS}^{1}(\mathrm{~m} / \mathrm{z})$ & $\mathrm{MS}^{2}(\mathrm{~m} / \mathrm{z})$ & Tentative identification \\
\hline \multirow[t]{2}{*}{ Purple } & 1 & 18.3 & 655 & $655[\mathrm{M}]^{+}$ & $493, \mathbf{3 3 1}^{\mathrm{z}}$ & Malvidin 3,5-diglucoside \\
\hline & 2 & 23.3 & 741 & $741[\mathrm{M}]^{+}$ & $579,493,331$ & Malvidin (malonylglucoside)-glucoside \\
\hline \multirow[t]{4}{*}{ Pink } & 1 & 16.2 & 595 & $595[\mathrm{M}]^{+}$ & 433,271 & Pelargonidin 3,5-diglucoside \\
\hline & 2 & 17.6 & 681 & $681[\mathrm{M}]^{+}$ & $647,519,475,271$ & Pelargonidin (malonylglucoside)-glucoside \\
\hline & 3 & 22.1 & 681 & $681[\mathrm{M}]^{+}$ & $519,433,271$ & Pelargonidin 3-(6' -malonylglucoside)-5-glucoside \\
\hline & 4 & 38.7 & 520 & $520[\mathrm{M}]^{+}$ & 433,271 & Pelargonidin 3-(6' -malonylglucoside) \\
\hline $\begin{array}{l}\text { White with } \\
\text { purple throat }\end{array}$ & 1 & 17.1 & 655 & $655[\mathrm{M}]^{+}$ & $493, \mathbf{3 3 1}$ & Malvidin 3,5-diglucoside \\
\hline $\begin{array}{l}\text { White with } \\
\text { pink throat }\end{array}$ & 1 & 17.7 & 625 & $625[\mathrm{M}]^{+}$ & $463, \mathbf{3 0 1}$ & Peonidin 3,5-diglucoside \\
\hline
\end{tabular}

${ }^{\mathrm{z}}$ Ions in bold were identified based on Sandhu and Gu (2010). 
(Sandhu and $\mathrm{Gu}, 2010$ ) and a second form tentatively identified as malvidin-(malonylglucoside)-glucoside, but the positioning of the glucosyl moieties could not be defined without further analysis. The anthocyanin responsible for the pink color was tentatively identified as pelargonidin, of which there were four different forms: pelargonidin 3,5-diglucoside, pelargonidin(malonylglucoside)-glucoside, pelargonidin 3-(6" malonylglucoside)-5-glucoside, and pelargonidin 3-(6" malonylglucoside). Again, in the case of pelargonidin-(malonylglucoside)-glucoside, the positioning of the glucosyl moieties could not be defined without further analysis. Similar to the purple corolla, in the white with purple throat, the anthocyanin was also tentatively identified as malvidin 3,5-diglucoside. Interestingly, the anthocyanin in the white with pink throat was peonidin 3,5-diglucoside rather than a pelargonidin form (Table 2).

We hypothesize that there are separate genes involved for flower color determination in $R$. simplex, some expressed on the corolla limb and others on the corolla throat. This is not unusual, because in petunia, there are different loci that are phenotypically expressed either on the limb or the tube of the corolla, and they show complex epistatic relations (Tornielli et al., 2009). In $R$. simplex the segregation for corolla limb color $94 \mathrm{P}: 30 \mathrm{PK}: 29 \mathrm{~W}$ fits a 9:3:4 segregation $(P=0.22)$, which is a modification of a 9:3:3:1 segregation resulting from recessive epistasis. This is similar to the segregation for flower color reported in Collinsia parviflora Lindl. [blue-eyed mary (Griffiths et al., 2012)]. The pathway for $R$. simplex is as follows:

$$
\begin{gathered}
w^{+} \quad m^{+} \\
\text {colorless } \rightarrow \text { pink } \rightarrow \text { purple }
\end{gathered}
$$

The $w$ and $m$ genes are not linked. When plants homozygous for white and pink corolla limb are crossed, the $F_{1}$ and $F_{2}$ are as follows:

$$
\begin{aligned}
& \text { (white) } w / w ; m^{+} / m^{+} \times(\text {pink }) w^{+} / w^{+} ; m / m \\
& \mathrm{~F}_{1} \quad w^{+} / w ; m^{+} / m \text { (purple) } \\
& \downarrow \\
& w^{+} / w ; m^{+} / m \times w^{+} / w ; m^{+} / m \\
& \downarrow \\
& \mathrm{F}_{2} \quad 9 w^{+} /-; m^{+} /- \text {(purple) } 9 \\
& 3 w^{+} /-; m / m \text { (pink) } 3 \\
& 3 w / w ; m^{+} /- \text {(white) } 4 \\
& 1 w / w ; m / m \text { (white) }
\end{aligned}
$$

The $w$ allele is epistatic on $m^{+}$and $m$, so that $m^{+}$and $m$ can be expressed only in the presence of $w^{+}$. Using the petunia anthocyanin pathway as a model (Holton and Cornish, 1995; Tornielli et al., 2009), $w^{+}$and $m^{+}$could possibly correspond to genes coding for or controlling the activities of $\mathrm{F} 3 \mathrm{H}$ and $\mathrm{F}^{\prime} 5^{\prime} \mathrm{H}$, respectively, and purple malvidin would be formed. If the pathway is blocked at the second gene, dyhidrokaempferol would be converted to pink pelargonidin. In the presence of $w$, naringenin would not be converted to dyhidrokapemferol resulting in white color (Fig. 2A).

For the corolla throat, the segregation of color $118 \mathrm{P}: 35 \mathrm{PK}$ fits a 3:1 segregation $(P=0.54)$. The purple color is the result of a dominant gene possibly coding for or controlling $\mathrm{F}^{\prime} 5^{\prime} \mathrm{H}$
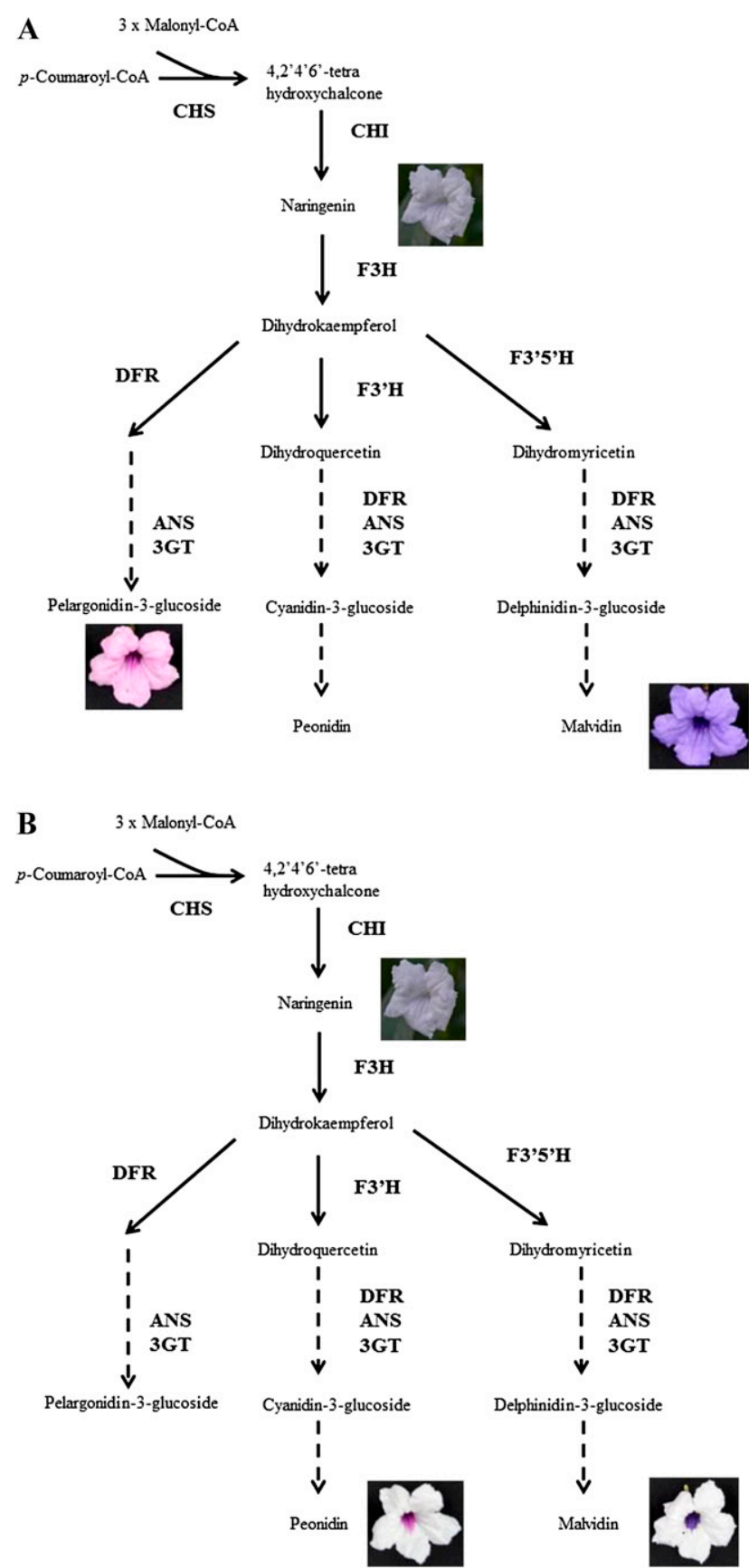

Fig. 2. Scheme of the flavonoid pathway in Ruellia simplex, simplified from the petunia flavonoid pathway, as in Holton and Cornish (1995) and Tornielli et al. (2009). CHS = chalcone synthase, $\mathrm{CHI}=$ chalcone flavanone isomerase; $\mathrm{F} 3 \mathrm{H}=$ flavanone 3-hydroxylase; $\mathrm{F}^{\prime} \mathrm{H}$ and $\mathrm{F}^{\prime}{ }^{\prime} 5^{\prime} \mathrm{H}=$ flavonoid $3^{\prime}$ and $3^{\prime} 5^{\prime}$ hydroxylase; DFR = dihydroflavonol 4-reductase; ANS = anthocyanin synthase; 3GT $=$ anthocyanin 3-glucosyltransferase. Dashed lines indicate the presence of more than one intermediate, not shown in this scheme. (A) Anthocyanin pathway for the corolla limb color; (B) anthocyanin pathway for the corolla throat color.

activity, but this gene is only expressed in the tube. In the presence of the recessive allele, a second gene can be expressed, which could possibly be coding or controlling F3' $\mathrm{H}$. This enzyme converts dihydrokaempferol to dihydroquercetin, which is an intermediate of cyanidin, which is later converted to peonidin conferring pink color (Fig. 2B). 
In conclusion, the inheritance of flower colors in $R$. simplex can be explained by the inheritance of anthocyanin pigmentation, which is controlled by multiple genes that follow simple Mendelian genetics. The flavonoid pathway in $R$. simplex appears to be simpler than that of Petunia. The corolla limb color is determined by two genes that show recessive epistasis. Delphinidin derivatives confer purple corolla limb color, whereas pelargonidin derivatives are responsible for the pink corolla limb color. Another gene is responsible for the corolla throat color. In this case the dominant allele confers delphinidin derivatives and purple throat color, whereas the recessive allele confers peonidin derivatives and pink throat color.

\section{Literature Cited}

Daniel, T.F. and T.I. Chuang. 1993. Chromosome numbers of newworld Acanthaceae. Syst. Bot. 18:283-289.

Daniel, T.F., T.I. Chuang, and M.A. Baker. 1990. Chromosome numbers of American Acanthaceae. Syst. Bot. 15:13-25.

Daniel, T.F., B.D. Parfitt, and M.A. Baker. 1984. Chromosome numbers and their systematic implications in some North-American Acanthaceae. Syst. Bot. 9:346-355.

Davies, K.M. 2004. An introduction to plant pigments in biology and commerce, p. 2-22. In: Davies, K.M. (ed.). Plant pigments and their manipulation. Annu. Plant Rev. 14. Blackwell, Oxford, UK.

Ezcurra, C. and T.F. Daniel. 2007. Ruellia simplex, an older and overlooked name for Ruellia tweediana and Ruellia coerulea (Acanthaceae). Darwiniana 45:201-203.

Forkmann, G. 1991. Flavonoids as flower pigments: The formation of the natural spectrum and its extension by genetic engineering. Plant Breed. 106:1-6.

Freyre, R., A. Moseley, S.B. Wilson, and G.W. Knox. 2012. Fruitless Ruellia simplex R10-102 ('Mayan Purple') and R10-108 ('Mayan White'). HortScience 47:1808-1814.

Freyre, R. and S.B. Wilson. 2014. Ruellia simplex R10-105-Q54 ('Mayan Pink'). HortScience 49:499-502.

Gilman, E.F. 1999. Ruellia brittoniana, Univ. Florida, Inst. Food Agr. Sci., Florida Coop. Ext. Serv., Environ. Hort. Dept. Fact Sheet FPS513. 8 July 2014. <http://edis.ifas.ufl.edu/fp513>.

Giusti, M.M. and R.E. Wrolstad. 2001. Characterization and measurement of anthocyanins by UV-visible spectroscopy, p. 1-13. In: Wrolstad, R.E. (ed.). Current protocols in food analytical chemistry. Wiley, Hoboken, NJ.
Griesbach, R.J. 1996. The inheritance of flower color in Petunia hybrida. J. Hered. 87:241-245.

Griesbach, R.J. 1998. The effect of the Ph 6 gene on the color of Petunia hybrida Vilm. flowers. J. Amer. Soc. Hort. Sci. 123:647650.

Griffiths, A.J.F., S.R. Wessler, S.B. Carroll, and J. Doebley. 2012. An introduction to genetic analysis. 10th Ed. Freeman, New York, NY.

Harborne, J.B. 1976. Functions of flavonoids in plants, p. 736-778. In: Goodwin, T.W. (ed.). Chemistry and biochemistry of plant pigments. Academic Press, New York, NY.

Holton, T.A. and E.C. Cornish. 1995. Genetics and biochemistry of anthocyanin biosynthesis. Plant Cell 7:1071-1083.

Hupp, K.V.S., A.M. Fox, S.B. Wilson, E.L. Barnett, and R.K. Stocker. 2009. Natural area weeds: Mexican petunia (Ruellia tweediana). Univ. Florida, Inst. Food Agr. Sci., Florida Coop. Ext. Serv., Environ. Hort. Dept. Publ. ENH1155. 7 May 2014. <http://edis.ifas.ufl.edu/ ep415>.

Mol, J., E. Grotewold, and R. Koes. 1998. How genes paint flowers and seeds. Trends Plant Sci. 3:212-217.

Paris, C.D. and W.J. Haney. 1958. Genetic studies in Petunia: Nine genes for flower color. Proc. Amer. Soc. Hort. Sci. 72:462472.

Royal Horticultural Society. 1995. Royal Horticultural Society colour chart. Royal Hort. Soc., London, UK.

Sandhu, A.K. and L. Gu. 2010. Antioxidant capacity, phenolic content, and profiling of phenolic compounds in the seeds, skin, and pulp of Vitis rotundifolia (muscadine grapes) as determined by HPLC-DADESI-MS. J. Agr. Food Chem. 58:4681-4692.

Schwinn, K.E. and K.M. Davies. 2004. Flavonoids, p. 92-149. In: Davies, K.M. (ed.). Plant pigments and their manipulation. Annu. Plant Rev. 14. Blackwell, Oxford, UK.

Tornielli, G., R. Koes, and F. Quattrocchio. 2009. The genetics of flower color, p. 269-299. In: Gerats, T. and J. Strommer (eds.). Petunia. Evolutionary, developmental and physiological genetics. Springer, New York, NY.

Tripp, E.A. 2014. The Tripp report. 20 June 2014. <http://www. trippreport.com/plants/ruellia-1>.

Tripp, E.A. and L.A. McDade. 2014. Time-calibrated phylogenies of hummingbirds and hummingbird-pollinated plants reject hypothesis of diffuse co-evolution. Aliso 31:89-103.

Wiering, H. and P. deVlaming. 1984. Inheritance and biochemistry of pigments, p. 49-76. In: Sink, K. (ed.). Petunia. 1st Ed. Springer, New York, NY. 